\title{
$\beta$-Adrenergic Receptors and Catecholamine Sensitive Adenylate Cyclase in Developing Rat Ventricular Myocardium: Effect of Thyroid Status
}

\author{
JEFFREY A. WHITSETT, ${ }^{(24)}$ JENNIFER POLLINGER, AND SUSAN MATZ \\ Children's Hospital Research Foundation, Children's Hospital, Newborn Division of Pediatrics, University of \\ Cincinnati College of Medicine, 231 Bethesda Avenue, Cincinnati, Ohio 45267, USA
}

\begin{abstract}
Summary
The present study was designed to describe the relationships among thyroid status, myocardial growth and myocardial $\beta$-adrenergic receptors in the developing rat ventricle. In normal rat myocardium the $\beta$-adrenergic binding capacity $\left(B_{\max }\right)$ for $\left.(-)-\left.\right|^{3} \mathrm{H}\right]$ DHA decreased with increasing age and heart size. In order to determine the effect of thyroid status on ventricular growth characteristics and $\beta$-adrenergic receptors, animals were rendered: (1) hypothyroid with propylthiouracil (PTU), (2) euthyroid with PTU and daily thyroxine $\left(\mathrm{T}_{4}\right)$ replacement, (3) hyperthyroid for several days with daily thyroxine injections or (4) normal controls with sham saline injections. Growth characteristics were similar in euthyroid and normal rat myocardium; ventricular weight, protein and DNA content were similar at postnatal days 5, 15 and 28 . Growth in hypothyroid pups was normal until postnatal day 14 at which time the heart weight and protein content were significantly lower than in normal or euthyroid pups, whereas the number of $\beta$-adrenergic receptors was decreased in hypothyroid myocardium at all ages studied. On postnatal day 5 the $(-)-\left[{ }^{3} \mathrm{H}\right] \mathrm{DHA}$ binding $\left(B_{\max }\right)$ was $37 \pm 9$ in hypothyroid myocardium compared to $63 \pm$ 8 fmole per mg protein mean \pm S.D. in euthyroid myocardium. The function of the $\beta$-adrenergic receptors was also decreased in hypothyroid as compared to euthyroid or normal myocardium as demonstrated by a decrease in maximal catecholamine sensitive adenylate cyclase activity in myocardial membranes at 28 days of age. Treatment of hypothyroid or normal pups with $T_{4}$ resulted in an increase in heart size, protein content and $\beta$-adrenergic receptors. Ventricular DNA content, which describes hyperplastic growth, was not decreased in hypothyroid rats demonstrating that postnatal hypertrophic but not hyperplastic ventricular growth is dependent on thyroid hormone.
\end{abstract}

\section{Speculation}

The decrease in $\beta$-adrenergic binding capacity in the rat ventricle during normal development is likely to reflect the decreasing proportion of sarcolemmal as compared to total ventricular proteins which occurs during hypertrophic growth. $\beta$-Adrenergic receptors are decreased in ventricles from hypothyroid rats at all ages and the decreased production of CAMP in response to (-)epinephrine in hypothyroid pups may relate to the decreased numbers of $\beta$-adrenergic receptors. Changes in thyroid status are highly associated with both $\beta$-adrenergic receptor status and the hypertrophic growth of the ventricular myocardium. We speculate that thyroid hormone is an important regulator of these changes during normal development.

Catecholamines regulate cardiac rate and contractility by their interactions with adrenergic receptors present on sarcolemmal membranes. The effects of $\beta$-adrenergic agonists on cardiac function are dependent upon the stimulation of the enzyme adenylate cyclase which increases intracellular $3^{\prime}, 5^{\prime}$ cyclic adenosine monophosphate (cAMP). $\beta$-Adrenergic responses and receptors have been identified in the mammalian myocardium early in development $(1,2,7,19)$. The number of $\beta$-adrenergic receptors increases during development and a direct relationship has been postulated between increasing sarcolemmal surface area and $\beta$-adrenergic receptor number during growth of the rat heart $(2,19)$. It has been previously suggested that $\beta$-adrenergic receptors on the myocyte may be regulated in part by cell size. There is evidence that myocardial growth and hypertrophy are also regulated by thyroid hormones in the developing rat as well as in the adult rat $(4,13)$. Numerous studies have also supported the interrelationships among increased thyroid gland activity, increased $\beta$-adrenergic sensitivity and increased numbers of myocardial $\beta$-adrenergic receptors during hyperthyroidism $(3,6,16-18,21)$. Indeed, exposure of the myocardium to thyroid hormone in vitro and the administration of pharmacologic concentrations of thyroid hormones in vivo result in myocardial hypertrophy and increased number of $\beta$-adrenergic receptors in various myocardial preparations $(3,6,16-18,21)$. In addition, Tse et al. (17) demonstrated increased catecholamine-sensitive adenylate cyclase activity, decreased cAMP phosphodiesterase and decreased c-GMP dependent protein kinase activity in ventricles from hyperthyroid rats (17). These authors have suggested that changes in these various biochemical parameters may account for the increased $\beta$-adrenergic sensitivity found in the myocardium from hyperthyroid animals (17). The role of hypothyroidism in the regulation of $\beta$ adrenergic receptors in the heart has not been as extensively studied. A small reduction in $\beta$-adrenergic receptors and a large decrease in the numbers of $\alpha$-adrenergic receptors were demonstrated in myocardial homogenates from hypothyroid adult rats $(3,6)$; however, correlation between the decreased myocardial $\beta$ adrenergic receptors and catecholamine sensitive adenylate cyclase activity were not demonstrated in these studies.

In addition to the direct effects of thyroid status on the $\beta$ adrenergic system in the adult myocardium, thyroid hormones exert potent maturational and growth effects on numerous organs, including brain, lung, liver and intestine (9). The possible effect of altered thyroid status on the growth of the myocardium during development has not been as extensively investigated as these other organs. The present study was therefore designed to determine the relationships among thyroid status, myocardial growth, and myocardial $\beta$-adrenergic receptors in the developing rat ventricle. In this study, we demonstrate, (1) the normal ontogeny of $\beta$-adrenergic receptor binding in the rat ventricular myocardium; (2) that hypothyroidism results in a marked decrease in myocardial $\beta$-adrenergic receptors at all ages studied; (3) that decreased ventricular $\beta$-adrenergic receptors are associated with decreased catecholamine dependent adenylate cyclase activity; and (4) that thyroid hormone or thyroid hormone dependent factors are required for the postnatal hypertrophic growth of the rat heart. 


\section{MATERIALS AND METHODS}

Animals. Congenital hypothyroidism and thyroid replacement procedures were performed essentially as previously described (20). Timed-bred Wistar rats were purchased from Charles River Corp. Dams were fed standard rat chow and maintained in individual cages in a $12 \mathrm{~h}$ light-dark cycle. Three groups of animals were maintained in individual cages and treated as follows: Group I, Hypothyroid rats were treated by adding $0.05 \%$ propylthiouracil (PTU) to their drinking water from day 18 of gestation until the time of sacrifice. Pups were nursed in litters of less than 10 pups with their mothers until sacrifice. Group $I I$, Euthyroid control rats were maintained on $0.05 \%$ PTU and the pups were injected subcutaneously each day with thyroxine $\left(\mathrm{T}_{4}\right)$ in $0.9 \% \mathrm{NaCl} 0.1 \mathrm{mM} \mathrm{NaOH}$ as follows: $0.05 \mu \mathrm{g}$ on days $2-5,0.1$ $\mu \mathrm{g}$ on days $6-14$, and $0.30 \mu \mathrm{g}$ on days $15-28$, as described by Hamburgh et al. (10). Group III, Untreated control rats were maintained with the dam in litters of less than 10 . Sham injections with $0.1 \mathrm{ml}$ of $0.9 \%$ saline were performed daily.

Hypothyroid adults. Adult female Wistar rats $(250-270 \mathrm{~g})$ were also maintained on $0.05 \%$ PTU for $6 \mathrm{wk}$ and compared with female controls of the same weight. Serum thyroxine was determined by a standard clinical radioimmunoassay in serum from individual animals collected after decapitation. The limit of detection for $\mathrm{T}_{4}$ was $1.0 \mu \mathrm{g} / \mathrm{dl}$.

Hyperthyroid animals. Rat pups were made hyperthyroid between days 7-14 and between days 24 and 28 of age by treatment with $3 \mathrm{mg} / \mathrm{kg} \mathrm{T}_{4}$ (intraperitoneal), as described by Williams et al. (21).

Materials. (-)- $\left[{ }^{3} \mathrm{H}\right]$ Dihydroalprenolol $(56 \mathrm{Ci} / \mathrm{mmole}),\left[\alpha^{32} \mathrm{P}\right]-$ ATP and $\left[{ }^{3} \mathrm{H}\right]$ cAMP were purchased from New England Nuclear Corp. (Boston, MA). (-)-Norepinephrine- $\mathrm{HCl},(-)$-epinephrine bitartrate, calf thymus DNA, $(-)$-thyroxine $\left(T_{4}\right),(-)$-triiodothyronine $\left(\mathrm{T}_{3}\right)$, propylthiouracil and other reagents were purchased from Sigma Chemical Co. (St. Louis, MO). (-)-Propranolol, (-)-alprenolol and (+)-propranolol were obtained from Ayerst Laboratories (Rouses Point, NY). (-)-Phentolamine mesylate was obtained from Ciba Pharmaceuticals Co. (Summit, NJ).

Membrane preparation. Animals were weighed and sacrificed by decapitation. The hearts were carefully dissected from atrial and mediastinal structures, weighed, diced and placed in iced buffer containing $250 \mathrm{mM}$ sucrose, $1 \mathrm{mM}$ EGTA and $5 \mathrm{mM}$ Tris- $\mathrm{HCl}$, pH 7.2 (STE). Ventricles from entire litters were pooled to obtain prenatal samples; tissue from two or more pups was pooled for samples at 5 days of age from four or more separate litters per group. Other samples were generally obtained from individual animals in these same litters followed sequentially. Attempts were made to maintain approximately equal numbers of pups in each litter (7-10 pups).

The washed ventricular tissue was homogenized with a Tekmar Tissuemizer (Tekmar Co., Cincinnati, $\mathrm{OH}$ ) in 20 volumes of iced STE and homogenized by three 5 -sec bursts at high setting as previously described (19). Samples of the crude homogenates were obtained for DNA and protein determinations. The homogenate was poured through four layers of gauze and centrifuged at 30,000 $\times g$ for $10 \mathrm{~min}$. The pellet was resuspended in iced STE and centrifuged again at the same setting. The final pellet was resuspended in STE to a membrane protein concentration of $5 \mathrm{mg} / \mathrm{ml}$ as determined by the method of Lowry et al. (12) using bovine serum albumin as the standard (10). In preliminary experiments, greater than $95 \%$ of the starting adenylate cyclase activity was recovered in this membrane fraction and the discarded supernatant lacked significant $\beta$-adrenergic receptors and adenylate cyclase activity. DNA was determined in the whole homogenate by the method of Burton (5), using calf thymus DNA as standard (Sigma).

Binding studies. Binding studies were performed in triplicate assays by filtration as previously described $(19,20)$, using $250 \mu \mathrm{g}$ of ventricular protein $(50 \mu \mathrm{l})$ in buffer containing $10 \mathrm{mM} \mathrm{MgCl}$, $50 \mathrm{mM}$ Tris- $\mathrm{HCl}(\mathrm{pH} \mathrm{7.4)}$ and increasing concentrations (0.2-5 $\mathrm{mM}$ ) of (-)-[ $\left.{ }^{3} \mathrm{H}\right] \mathrm{DHA}$ (56 Ci/mmole, New England Nuclear Co.). Nonspecific binding was also determined in triplicate in the presence of $1 \mu \mathrm{M}(-)$-alprenolol or $1 \mu \mathrm{M}(-)$-propranolol which gave identical results. The assay was incubated for $20 \mathrm{~min}$ at $30^{\circ}$ during which equilibrium was achieved at the lowest ligand concentration $(0.2 \mu \mathrm{M})$. Assays were terminated by rapid filtration through Whatman glass fiber filters which were washed four times with $4 \mathrm{ml}$ of iced assay buffer and were counted at $25 \%$ efficiency by standard scintillation technique.

Equilibrium data were obtained at five or six (-)- $\left[{ }^{3} \mathrm{H}\right] \mathrm{DHA}$ concentrations and the $K_{D}$ and $B_{\max }$ were determined by the method of Scatchard. The linear regression coefficients were

Table 1. Effects of hypothyroidism and thyroxine treatment on heart (ventricular) growth characteristics in the postnatal rat pup ${ }^{1}$

\begin{tabular}{|c|c|c|c|c|c|c|c|}
\hline Group & $\begin{array}{l}\text { Body wt } \\
\text { (g) }\end{array}$ & $\begin{array}{l}\text { Heart wt } \\
(\mathrm{g})\end{array}$ & $\begin{array}{c}\text { Heart Protein } \\
\text { mg/heart }\end{array}$ & $\begin{array}{c}\text { Heart Protein } \\
\mathrm{mg} / \mathrm{g} \text { heart }\end{array}$ & $\begin{array}{l}\text { Heart DNA } \\
\text { (mg/heart) }\end{array}$ & $\frac{\text { Protein }}{\text { DNA }(\mathrm{mg} / \mathrm{mg})}$ & $\frac{\text { Heart Wt. }}{\text { Body Wt. (mg/g) }}$ \\
\hline \multicolumn{8}{|l|}{ I (PTU) } \\
\hline Day 5 & $\begin{array}{c}10.8 \pm 1.4 \\
n=14\end{array}$ & $\begin{array}{c}0.051 \pm 0.006 \\
n=14\end{array}$ & $\begin{array}{c}7.55 \pm 0.71 \\
n=14\end{array}$ & $\begin{array}{c}148 \pm 8^{2 e} \\
n=14\end{array}$ & $\begin{aligned} 0.370 & \pm 0.088 \\
n & =3\end{aligned}$ & $\begin{array}{c}16.3 \pm 1.8 \\
n=6\end{array}$ & $\begin{array}{c}4.76 \pm 0.63 \\
n=14\end{array}$ \\
\hline Day 15 & $\begin{array}{c}21.5 \pm 4.1^{2 a} \\
n=14\end{array}$ & $\begin{array}{c}0.069 \pm 0.012^{2 a} \\
n=14\end{array}$ & $\begin{array}{c}11.0 \pm 1.7^{2 a} \\
n=14\end{array}$ & $\begin{array}{c}155 \pm 28 \\
n=10\end{array}$ & $\begin{array}{c}0.585 \pm 0.098^{2 f} \\
n=8\end{array}$ & $\begin{array}{c}19.1 \pm 6.7 \\
n=8\end{array}$ & $\begin{array}{c}3.28 \pm 0.56 \\
n=14\end{array}$ \\
\hline Day 28 & $\begin{array}{c}37.5 \pm 4.6^{2 a} \\
n=24\end{array}$ & $\begin{array}{c}0.105 \pm 0.026^{2 a} \\
n=24\end{array}$ & $\begin{array}{c}16.1 \pm 4.3^{2 a} \\
n=20\end{array}$ & $\begin{array}{c}151 \pm 21^{2 e} \\
n=20\end{array}$ & $\begin{aligned} 0.732 & \pm 0.081^{2 d} \\
n & =9\end{aligned}$ & $\begin{array}{c}28.8 \pm 7.2^{2 a} \\
n=8\end{array}$ & $\begin{array}{c}2.90 \pm 0.75^{2 d} \\
n=24\end{array}$ \\
\hline \multicolumn{8}{|c|}{$\mathrm{II}\left(\mathrm{PTU}+\mathrm{T}_{4}\right)$} \\
\hline Day 5 & $\begin{array}{c}11.9 \pm 1.7 \\
n=14\end{array}$ & $\begin{array}{c}0.054 \pm 0.010 \\
n=14\end{array}$ & $\begin{array}{c}8.23 \pm 1.27 \\
n=14\end{array}$ & $\begin{array}{c}152 \pm 10^{2 c} \\
n=14\end{array}$ & $\begin{array}{c}0.423 \pm 0.118 \\
n=3\end{array}$ & $\begin{array}{c}16.0 \pm 1.7 \\
n=3\end{array}$ & $\begin{array}{c}4.48 \pm 0.93 \\
n=14\end{array}$ \\
\hline Day 15 & $\begin{aligned} 27.6 & \pm 5.5 \\
n & =8\end{aligned}$ & $\begin{array}{c}0.106 \pm 0.015 \\
n=8\end{array}$ & $\begin{array}{c}18.1 \pm 2.4 \\
n=8\end{array}$ & $\begin{array}{c}171 \pm 7 \\
n=4\end{array}$ & $\begin{aligned} 0.883 & \pm 0.098 \\
n & =4\end{aligned}$ & $\begin{array}{c}20.3 \pm 3.5 \\
n=4\end{array}$ & $\begin{array}{c}3.91 \pm 0.63 \\
n=8\end{array}$ \\
\hline Day 28 & $\begin{aligned} 69.1 & \pm 7.1^{2 c} \\
n & =8\end{aligned}$ & $\begin{array}{c}0.229 \pm 0.027^{2 c} \\
n=8\end{array}$ & $\begin{array}{l}34.5 \pm 4.3^{2 c} \\
\quad n=8\end{array}$ & $\begin{array}{l}172 \pm 12^{2 c} \\
n=4\end{array}$ & $\begin{array}{c}0.615 \pm 0.066^{2 c} \\
n=4\end{array}$ & $\begin{array}{c}60.3 \pm 4.2 \\
n=4\end{array}$ & $\begin{array}{c}3.35 \pm 0.59 \\
n=8\end{array}$ \\
\hline \multicolumn{8}{|l|}{ III (Control) } \\
\hline Day 5 & $\begin{array}{c}8.5 \pm 0.6^{2 b} \\
n=8\end{array}$ & $\begin{array}{c}0.041 \pm 0.003 \\
n=4\end{array}$ & $\begin{array}{c}7.94 \pm 0.90 \\
n=4\end{array}$ & $\begin{array}{c}195 \pm 12 \\
n=4\end{array}$ & $\begin{aligned} 0.245 & \pm 0.024 \\
n & =4\end{aligned}$ & $\begin{array}{c}16.6 \pm 2.2 \\
n=3\end{array}$ & $\begin{array}{l}4.79 \pm 0.48 \\
n=4\end{array}$ \\
\hline Day 15 & $\begin{aligned} 27.5 & \pm 3.7 \\
n & =7\end{aligned}$ & $\begin{array}{c}0.098 \pm 0.015 \\
n=6\end{array}$ & $\begin{array}{c}19.3 \pm 3.9 \\
n=6\end{array}$ & $\begin{array}{l}198 \pm 38 \\
n=6\end{array}$ & $\begin{aligned} 0.774 & \pm 0.086 \\
n & =5\end{aligned}$ & $\begin{array}{c}27.5 \pm 5.4 \\
n=4\end{array}$ & $\begin{array}{c}3.53 \pm 0.41 \\
n=6\end{array}$ \\
\hline Day 28 & $\begin{array}{c}84.3 \pm 11.0 \\
n=11\end{array}$ & $\begin{array}{c}0.287 \pm 0.019 \\
n=7\end{array}$ & $\begin{array}{c}54.3 \pm 7.5 \\
n=4\end{array}$ & $\begin{array}{c}194 \pm 17 \\
n=4\end{array}$ & $\begin{array}{c}0.788 \pm 0.017 \\
n=4\end{array}$ & $\begin{array}{c}68.8 \pm 9.5 \\
n=4\end{array}$ & $\begin{array}{c}3.69 \pm 0.45 \\
n=7\end{array}$ \\
\hline
\end{tabular}

'Data represents mean \pm S.D. for individual determination or a pooled group; $n=$ the number of separate determinations when different from the number of pups. Group I (PTU), Group II (PTU + $\mathrm{T}_{4}$ ), and Group III (control) were treated as described in "Materials and Methods."

${ }^{2}$ S.D.: $(a) \mathrm{I}<\mathrm{II}$ or III $P<0.0 \mathrm{I} ;(b)$ III $<$ II or I $P<0.01 ;(c)$ II $<\mathrm{III}, P<0.01 ;(d) \mathrm{I}<\mathrm{III}, P<0.05 ;(e) \mathrm{I}<\mathrm{III}, P<0.01$; and $(f)$ I $<\mathrm{II}, P<0.01$. 
greater than 0.9 for individual saturation experiments suggesting the presence of a single class of binding sites for $(-)-\left[{ }^{3} \mathrm{H}\right] \mathrm{DHA}$ under these conditions. Nonspecific binding was approximately $20 \%$ of the total binding at the $K_{\mathrm{D}}$. Binding was not altered by the addition of the $\alpha$-adrenergic antagonist phentolamine $(10 \mu \mathrm{M})$.

Adenylate cyclase activity. Adenylate cyclase was determined at $30^{\circ} \mathrm{C}$ in triplicate by a modification of the method of Salomon et al. (14). The assay contained 50-75 $\mu \mathrm{g}$ membrane protein, $0.2 \mathrm{mM}$ $\left[\alpha-{ }^{32} \mathrm{P}\right] \mathrm{ATP}(2 \mu \mathrm{Ci}), 3.0 \mathrm{mM} \mathrm{MgCl}, \operatorname{lmM~}\left[{ }^{3} \mathrm{H}\right] \mathrm{cAMP}(0.001 \mu \mathrm{Ci})$, $100 \mathrm{mM}$ Tris- $\mathrm{HCl}$, pH 7.4, a creatine phosphokinase-phosphocreatine regeneration system, $0.1 \%$ bovine serum albumin, 12.5 $\mathrm{mM}$ sucrose, $0.05 \mathrm{mM}$ EGTA and added hormone and guanine nucleotide. The assay mixture was preincubated for $5 \mathrm{~min}$ at $30^{\circ} \mathrm{C}$ and the reaction initiated by the addition of labeled ATP. Basal and hormone-stimulated cyclic AMP production was entirely linear for at least $30 \mathrm{~min}$ and triplicate determinations usually varied less than $5 \%$. Column recoveries of $\left[{ }^{3} \mathrm{H}\right] \mathrm{cAMP}$ varied from $60-75 \%$ and were not altered by theophylline.

Statistical analysis. The significance of differences between the three groups was determined by a one-way analysis of variance, utilizing a Neumann-Kuels correction for multiple groups (15). Where comparisons were made between two treatment groups, difference was assessed by Student's $t$ test. Scatchard plots were analyzed by linear regression analysis.

\section{RESULTS}

Rat pups nursed by dams on PTU (Group I, Hypothyroid) manifested the characteristics of congenital hypothyroidism. Growth was nearly normal until 14 days of postnatal age in all groups; thereafter, growth rate decreased and the day of eye opening and the appearance of hair growth was delayed in the hypothyroid group. These hypothyroid pups had characteristic short snouts and were both ataxic and less active than Group II $\left(\mathrm{PTU}+\mathrm{T}_{4}\right)$ or Group III (untreated control) pups. Serum thyroxine concentration was below the level of detection $(1 \mu \mathrm{g} / \mathrm{dl})$ in group I pups at all ages studied. Somatic and heart weight were not significantly altered in the hypothyroid pups on day 5 compared to both control groups, but Group I pups were markedly smaller than controls (II or III) by day 15 . Ventricular weight and protein content were markedly decreased in Group I as compared to Groups II and III animals at days 15 and 28, $P<0.01$ (Table 1). Ventricular DNA content was not decreased in the hypothyroid pups, supporting the concept that the lack of thyroid hormone during development results primarily in a decrease in hypertrophic growth rather than hyperplastic growth. This loss of ventricular mass was not recovered in older hypothyroid pups up to 40 days of age.

Effect of $T_{4}$ on ventricular growth. Treatment of 25-day-old
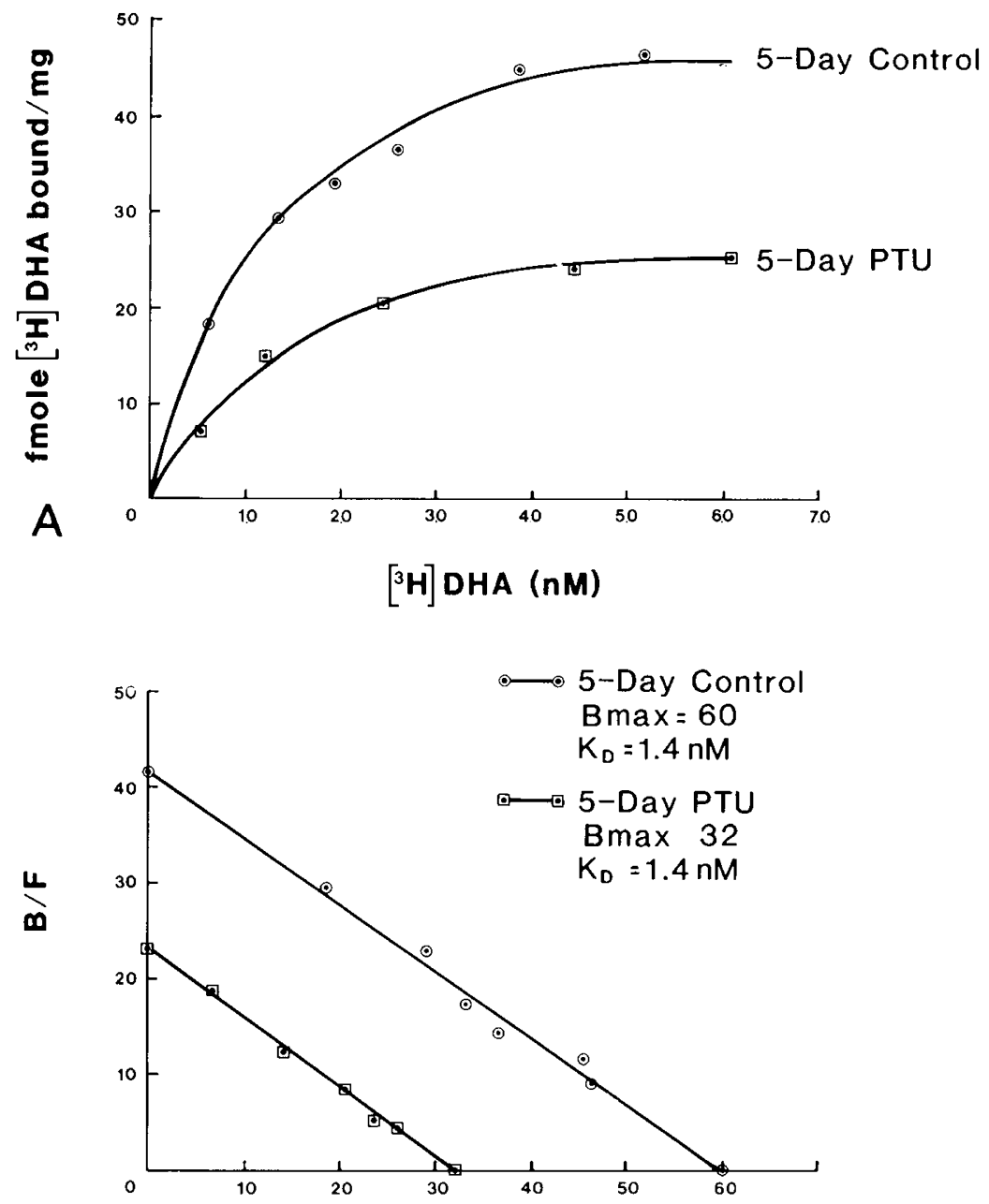

B fmole $\left[{ }^{3} \mathrm{H}\right] \mathrm{DHA}$ bound $/ \mathrm{mg}$

Fig. $1 a$ and $b$. Saturation experiment and Scatchard analysis of $(-)-\left[{ }^{3} \mathrm{H}\right] \mathrm{DHA}$ binding to rat ventricular myocardium at 5 days of age. Two ventricles from 5-day-old animals were pooled for each preparation. Total and nonspecific $(-)-\left[{ }^{3} \mathrm{H}\right] \mathrm{DHA}$ binding was determined in triplicate at each $(-)-\left[{ }^{3} \mathrm{H}\right]$ DHA concentration. The $K_{D}$ and $B_{\max }$ were determined from the Scatchard plot. At 5 days of age the $\mathrm{K}_{\mathrm{D}}=1.4$ and $\mathrm{B}_{\max }=60 \mathrm{fmole} \cdot \mathrm{mg}^{-1} \mathrm{membrane}$ protein in the control samples. The $\mathrm{K}_{\mathrm{D}}=1.4$ and $\mathrm{B}_{\max }=32 \mathrm{fmole} \cdot \mathrm{mg}^{-1}$ protein in the PTU-treated pups. 
chronically hypothyroid rat pups with $T_{4}$ resulted in a prompt increase in heart size and protein content (Table 3). Marked increase in ventricular weight and protein content was also noted in rat pups treated with $3 \mathrm{mg} / \mathrm{kg}$ thyroxine $\left(\mathrm{T}_{4}\right)$ at days 15 and 28 of postnatal age (Table 3 ).

$\beta$-Adrenergic receptors. (-)- $\left[{ }^{3} \mathrm{H}\right] \mathrm{DHA}$ bound to particulate fractions of fetal, neonatal and adult rat myocardium with properties characteristic of binding to a $\beta$-adrenergic receptor. Specific binding was rapid, reaching equilibrium by $20 \mathrm{~min}$ at $30^{\circ} \mathrm{C}$ at the lowest ligand concentration, $\left.0.1 \mathrm{nM}(-)-{ }^{3} \mathrm{H}\right] \mathrm{DHA}$. Binding was also rapidly reversible and showed stereo-selectivity for the (-)stereoisomer of propranolol. Agonist competition followed the order of potency $(-)$-isoproterenol $>(-)$-norepinephrine $=(-)$ epinephrine, typical of a $\beta_{1}$-adrenergic receptor. Scatchard plots of $(-)-\left[{ }^{3} \mathrm{H}\right] \mathrm{DHA}$ binding to ventricular membrane in all groups of animals were linear, suggesting the presence of a single class of binding sites, (Fig. la and $b$ ). Binding capacity (per mg protein) was higher in fetal and neonatal myocardium than in the mature adult myocardium at all $(-)-\left[{ }^{3} \mathrm{H}\right] \mathrm{DHA}$ concentrations and the decrease in the specific activity of $(-)-\left[{ }^{3} \mathrm{H}\right] \mathrm{DHA}$ binding decreased progressively and significantly with age and heart weight; slope $=-0.04$ fmoles per $\mathrm{mg}$ protein per $\mathrm{mg}$ increase in ventricular weight, $r=0.72, P<0.001$ (Fig. 2).

Thyroid status and the $\beta$-adrenergic receptors. Ventricular $\beta$ adrenergic receptors were significantly decreased in hearts from hypothyroid animals (Group I) at all ages studied, being reduced by approximately one-third that of control as early as 5 days of age (Figures $\mathrm{I} a$ and $b$ and Table 2). This reduction was apparent whether expressed per mg protein, per mg DNA or as $\beta$-adrenergic receptors recovered per heart (Fig. 3). Treatment of hypothyroid or euthyroid pups between days 25 and 28 with $5 \mu \mathrm{g} /$ day of $\mathrm{T}_{4}$ resulted in a marked increase in $\beta$-adrenergic receptors and ventricular protein (Table 3 ). Ventricular $\beta$-adrenergic receptors were also significantly increased compared to controls in hyperthyroid pups treated between days 7-15. Finally, ventricular membranes from adult animals which had been maintained on propylthiouracil for 6 wk also had a significant reduction in $\beta$-adrenergic receptors: $23.0 \pm 2.8, n=5$, as compared to $34.0 \pm 2.0$, fmoles $\mathrm{mg}^{-1}$ protein for control, $n=3, P<0.01$.
Thyroid status and adenylate cyclase activity. Because of the correlation between $\beta$-adrenergic receptor number and thyroid status, we determined catecholamine-sensitive adenylate cyclase activity in the ventricular membrane of the 28-day-old rat pups in hypothyroid, hyperthyroid and control animals. Basal enzyme activity and maximal GTP and $\mathrm{NaF}$ dependent activities were not altered by thyroid status. Maximal hormone sensitive adenylate cyclase activity in the developing rat heart required the presence of GTP. Adenylate cyclase activity in the presence of the maximally activating concentration of epinephrine $\left(5 \times 10^{-5} \mathrm{M}\right)$ was significantly decreased in the hypothyroid animals. Ventricular adenylate cyclase activity was not increased in the hyperthyroid pups on day 28 (Table 4). While maximal catecholamine dependent activation was decreased in the hypothyroid myocardial membrane preparations, the sensitivity to (-)-epinephrine $\left(\mathrm{EC}_{50}\right)$ was not altered (data not shown)

\section{DISCUSSION}

The present work describes the ontogeny of $\beta$-adrenergic receptors in the developing rat ventricular myocardium. It also demonstrates the role of varying thyroid status on both ventricular growth and on the numbers and function of ventricular $\beta$-adrenergic receptors. Thyroid hormone is required for the hypertrophic component of normal myocardial growth. Its excess induces marked ventricular hypertrophy in the suckling and weanling rat. The decrease in $\beta$-adrenergic receptors $\left(\mathrm{B}_{\max }\right)$ in hypothyroid pups was associated with a decrease in maximal activation of adenylate cyclase by (-)-epinephrine whereas in short term hyperthyroidism an increase in the $\beta$-adrenergic receptors $\left(\mathrm{B}_{\max }\right)$ was not associated with increased maximal catecholamine-dependent activation of the enzyme.

In studies from this laboratory and others, a relationship between $\beta$-adrenergic receptor number and heart weight during growth has been demonstrated. It has also been suggested that a major determinant of the $\beta$-adrenergic number (specific activity) is the amount of sarcolemmal protein which is likely to increase in relation to the increase in surface area of the cell which occurs during growth $(2,19)$. During hypertropic growth, nonsurface

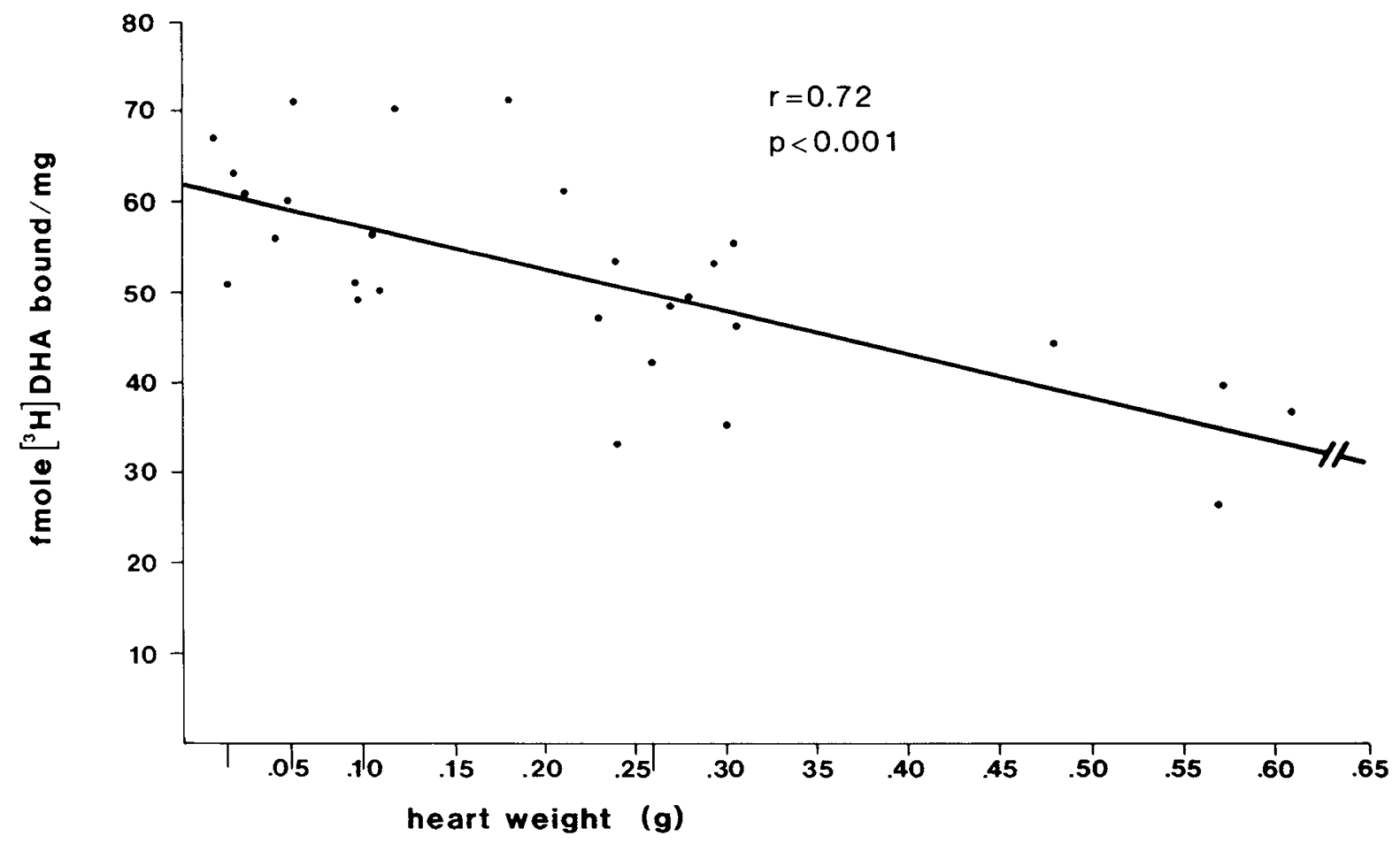

Fig. 2. Analysis of $(-)-\left[{ }^{3} \mathrm{DHA}\right]$ binding as a function of ventricular weight. The slope of the line determined by linear regression analysis $=-0.04$ fmole $\mathrm{mg}^{-1}$ protein $\mathrm{mg}^{-1}$ wet weight, $r=0.72, P<0.001$. The animals range in age from 20 days gestation to adulthood. 
Table 2. Effects of hypothyroidism and thyroxine treatment on heart $\beta$-adrenergic receptors in postnatal rats. $\beta$-Adrenergic receptor characteristics were determined with (-)- $\left.\Gamma^{3} H\right]$ dihydroalprenolol as described in "Materials and Methods." Values are mean $\pm S . D$.

\begin{tabular}{|c|c|c|c|c|}
\hline Group & $\begin{array}{l}\beta \text {-receptor fmole } / \mathrm{mg} \\
\text { membrane protein }\end{array}$ & $\begin{array}{c}\beta \text {-receptor } \\
\text { fmole/heart }\end{array}$ & $\begin{array}{l}\mathrm{K}_{\mathrm{D}} \\
\mathrm{nM}\end{array}$ & $\begin{array}{c}\text { Serum } \mathrm{T}_{4} \\
(\mu \mathrm{g} / \mathrm{dl})\end{array}$ \\
\hline \multicolumn{5}{|l|}{ I (PTU) } \\
\hline Day 5 & $\begin{array}{c}37.0 \pm 9.2 \mathrm{~b} \\
n=3\end{array}$ & $\begin{array}{c}115 \pm 62 b \\
n=3\end{array}$ & $\begin{aligned} 1.48 & \pm 0.69 \\
n & =3\end{aligned}$ & $<1.0$ \\
\hline Day 15 & $\begin{aligned} 26.0 & \pm 1.8 \mathrm{a} \\
n & =4\end{aligned}$ & $\begin{aligned} 74.9 & \pm 22.4 \mathrm{a} \\
n & =4\end{aligned}$ & $\begin{aligned} 1.31 & \pm 0.93 \\
n & =4\end{aligned}$ & $<1.0$ \\
\hline Day 28 & $\begin{aligned} 35.4 & \pm 9.4 \mathrm{c}, \mathrm{d} \\
n & =10\end{aligned}$ & $\begin{array}{c}380 \pm 96 \mathrm{a} \\
n=9\end{array}$ & $\begin{array}{c}1.56 \pm 0.78 \\
n=10\end{array}$ & $<1.0$ \\
\hline \multicolumn{5}{|c|}{ II $\left(\mathrm{PTU}+\mathrm{T}_{4}\right)$} \\
\hline Day 5 & $\begin{array}{c}62.7 \pm 8.3 \\
n=3\end{array}$ & $\begin{array}{c}217 \pm 62 \\
n=3\end{array}$ & $\begin{array}{c}1.50 \pm 0.20 \\
n=3\end{array}$ & $\begin{array}{r}<1.0-1.7 \\
n=8\end{array}$ \\
\hline Day 15 & $\begin{array}{c}56.8 \pm 9.2 \\
n=4\end{array}$ & $\begin{aligned} 370 & \pm 87 \\
n & =3\end{aligned}$ & $\begin{aligned} 1.63 & \pm 0.62 \\
n & =3\end{aligned}$ & $\begin{aligned} 6.23 & \pm 0.5 \\
n & =3\end{aligned}$ \\
\hline Day 28 & $\begin{array}{c}57.0 \pm 9.3 \\
n=5\end{array}$ & $\begin{aligned} 1510 & \pm 360 \\
n & =4\end{aligned}$ & $\begin{array}{c}2.26 \pm 0.50 \\
n=4\end{array}$ & $\begin{aligned} 1.7 & \pm 0.3 \\
n & =3\end{aligned}$ \\
\hline \multicolumn{5}{|l|}{ III (Control) } \\
\hline Day 5 & $\begin{array}{l}50.2(47.9-52.5) \\
\quad n=2\end{array}$ & $\begin{array}{c}209(193-225) \\
n=2\end{array}$ & $\begin{array}{l}1.65(1.57-1.73) \\
\quad n=2\end{array}$ & $\begin{array}{l}<1.0 \\
\quad n=4\end{array}$ \\
\hline Day 15 & $\begin{aligned} 49.0 & \pm 1.8 \\
n & =3\end{aligned}$ & $\begin{array}{l}341 \\
\text { pooled }\end{array}$ & $\begin{array}{l}1.73 \\
\text { pooled }\end{array}$ & $\begin{aligned} 7.5 & \pm 0.8 \\
n & =4\end{aligned}$ \\
\hline Day 28 & $\begin{array}{c}45.8 \pm 6.8 \mathrm{e} \\
n=6\end{array}$ & $\begin{aligned} 1400 & \pm 340 \\
n & =6\end{aligned}$ & $\begin{aligned} 2.21 & \pm 0.39 \\
n & =6\end{aligned}$ & $\begin{array}{c}3.8 \pm 0.6 \\
n=4\end{array}$ \\
\hline
\end{tabular}

' S.D.: (a) I $<$ II or III $P<0.01 ;(b)$ I $<$ II or III $P<0.05 ;(c)$ I $<$ III $P<0.05 ;(d)$ I $<$ II $P<0.01$; and $(e)$ III $<$ II $P<0.05$.

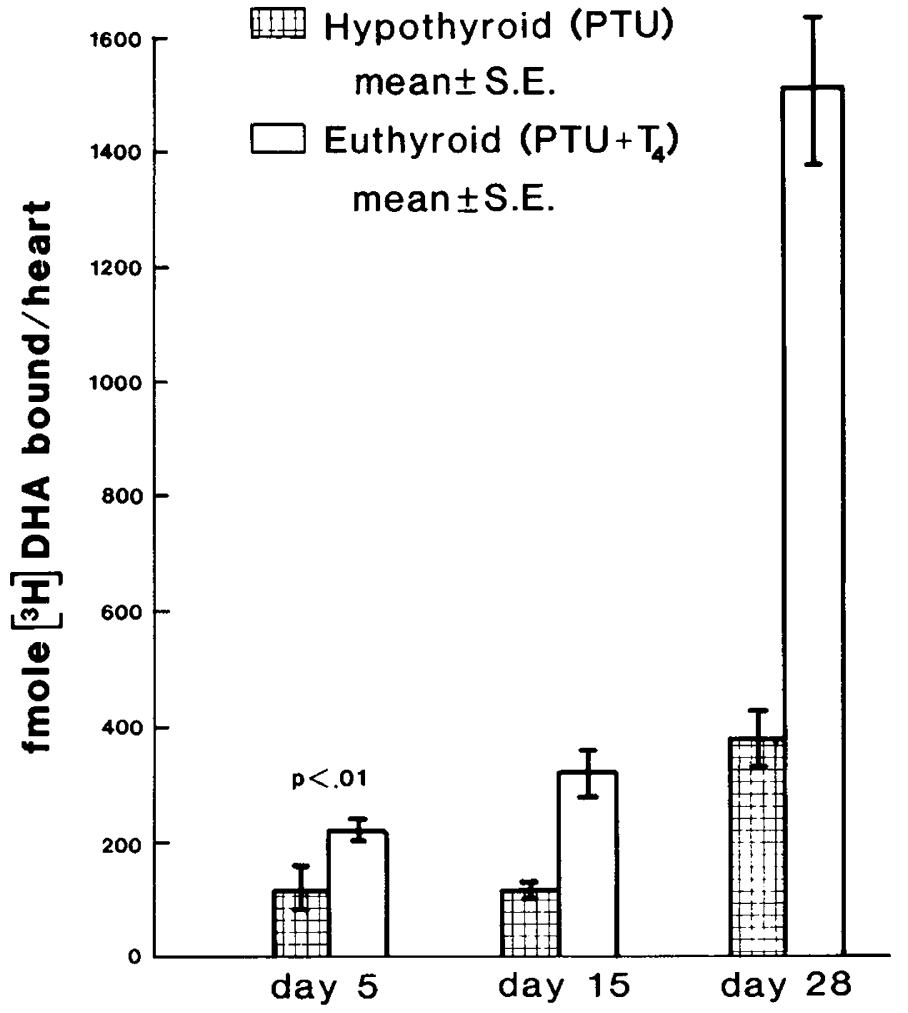

Age

Fig. 3. Effect of hypothyroidism on ventricular $\beta$-adrenergic receptors. The bar graph represents (-)-[ $\left.{ }^{3} \mathrm{H}\right] \mathrm{DHA}$ binding (fmole $\cdot$ heart $^{-1}$ ) for hypothyroid (Group I) and euthyroid rat pups (Group II) at 5, 15 and 28 days of age. Results are the mean \pm S.E. for 3-12 separate preparations.

proteins of the cell would likely increase in excess of sarcolemmal proteins $(11,13,14)$. Therefore, if $\beta$-receptor density (per unit surface area) remains unchanged during advancing age, the specific activity of the $\beta$-receptor, expressed per $\mathrm{mg}$ protein, would be expected to decrease.
The present study was designed to determine the possible regulation by thyroid hormones of the development and function of myocardial $\beta$-adrenergic receptors as well as myocardial growth in the rat. As previously shown by Brasel and Winik (4), a marked reduction in heart weight occurred in the hypothyroid pups compared to normal or euthyroid pups. In the present study, hyperplastic growth, as assessed by DNA content, was not affected by hypothyroidism at any age. However, a marked reduction in cell size and protein content (hypertrophic growth) was observed in the hypothyroid pups. Ventricular weight and protein content in hypothyroid pups never exceeded that attained in normal pups at 15 days of age. Replacement $\mathrm{T}_{4}$ given to pups on days 25 to 28 of age caused an immediate increase in heart size and protein content, demonstrating the potential reversibility of propylthiouracil-induced myocardial growth retardation in the weanling rat. It is also of interest to note that increased serum $\mathrm{T}_{3}$ and $\mathrm{T}_{4}$ concentration occurs in the weanling rat in the second or third wk of life. The timing is associated with a marked increase in hypertrophic myocardial growth in the rat $(8,22)$. Earlier thyroid treatment of the rat pups between postnatal days 7 and 15 also significantly increased ventricular size, suggesting that the tissue sensitivity to the hypertrophic effects of thyroid hormones occurs in the rat ventricle during the suckling and weanling period, as well as in the adult.

It is unclear whether the effects of thyroid hormones were direct or whether they were mediated by nutritional or other growth factors which might also be modulated by changes in thyroid status. The absence of effects of hypothyroidism on early postnatal growth might have been due to the short duration of PTU treatment (beginning day 18 of gestation); however, the number of myocardial $\beta$-adrenergic receptors were significantly reduced in 5-day-old PTU treated pups as compared to normal pups. Finally, the lack of a deleterious effect of hypothyroidism on myocardial growth at five days of age suggests that factors other than thyroid hormones may control myocardial growth before 5 days of postnatal age.

The present study demonstrates a clear decrease in $\beta$-adrenergic receptors in myocardium of hypothyroid pups at 5,15 and 28 days of age as well as in the adult whether expressed per unit protein or heart weight. The function of the $\beta$-adrenergic receptor was also decreased in relative proportion to the change in $\beta$-receptor density at 28 days as assessed by the decreased ability of (-)epinephrine to maximally stimulate adenylate cyclase. Basal-, 
Table 3. Effect of thyroid status on $\beta$-adrenergic receptors in developing rat myocardium ${ }^{1}$

\begin{tabular}{|c|c|c|c|c|c|c|c|}
\hline \multirow[b]{2}{*}{ Group } & & \multirow[b]{2}{*}{$\begin{array}{c}\text { Body wt } \\
\text { (g) }\end{array}$} & \multirow[b]{2}{*}{$\begin{array}{c}\text { Heart wt } \\
(\mathrm{g})\end{array}$} & \multicolumn{3}{|c|}{$(-)-\left[{ }^{3} \mathrm{H}\right] \mathrm{DHA}$ binding } & \multirow[b]{2}{*}{$\begin{array}{c}\text { Serum } \mathrm{T}_{4} \\
\mu \mathrm{g} / \mathrm{dl}\end{array}$} \\
\hline & & & & $\begin{array}{l}\mathrm{K}_{\mathrm{D}} \\
\mathrm{nM}\end{array}$ & $\begin{array}{l}\beta \text {-recentor } \\
\text { fmole } / \mathrm{mg}\end{array}$ & $\begin{array}{l}\beta \text {-receptor } \\
\text { fmole/heart }\end{array}$ & \\
\hline la & $\begin{array}{l}\text { Euthyroid } \\
\text { (15 days })\end{array}$ & $\begin{array}{c}26.9 \pm 4.5 \\
n=12\end{array}$ & $\begin{array}{c}0.100 \pm 0.020 \\
n=12\end{array}$ & $\begin{aligned} 1.63 & \pm 0.62 \\
n & =4\end{aligned}$ & $\begin{array}{c}56.8 \pm 9.2 \\
n=4\end{array}$ & $\begin{array}{c}332 \pm 75 \\
n=3\end{array}$ & \\
\hline $1 b$ & $\begin{array}{l}\text { Hyperthyroid } \\
\text { (15 days) }\end{array}$ & $\begin{array}{c}24.3 \pm 2.6 \\
n=12\end{array}$ & $\begin{aligned} 0.128 & \pm 0.038^{2} \\
n & =12\end{aligned}$ & $\begin{array}{c}1.84 \pm 0.41 \\
n=4\end{array}$ & $\begin{array}{c}82.5 \pm 18.6^{1} \\
n=4\end{array}$ & $\begin{aligned} 609 & \pm 157^{1} \\
n & =4\end{aligned}$ & \\
\hline $2 a$ & $\begin{array}{l}\text { Hypothyroid } \\
\text { (28 days) }\end{array}$ & $\begin{array}{c}41.8 \pm 7.3 \\
n=5\end{array}$ & $\begin{array}{c}0.12 \pm 0.02 \\
n=5\end{array}$ & $\begin{array}{l}2.86 \\
\text { pooled }\end{array}$ & 39 & 409 & $<1.0$ \\
\hline $2 b$ & $\begin{array}{l}\text { Hypothyroid }+\mathrm{T}_{4} \\
\quad \text { (day } 25-28)\end{array}$ & $\begin{array}{c}41.6 \pm 1.6 \\
n=5\end{array}$ & $\begin{aligned} 0.17 & \pm 0.01^{2} \\
n & =5\end{aligned}$ & $\begin{array}{l}2.72 \\
\text { pooled }\end{array}$ & 70 & 1246 & $\begin{array}{c}22.1 \pm 6.3 \\
n=5\end{array}$ \\
\hline $3 \mathrm{a}$ & $\begin{array}{l}\text { Euthyroid control } \\
\text { ( } 29 \text { days) }\end{array}$ & $\begin{array}{c}88.0 \pm 5.6 \\
n=3\end{array}$ & $\begin{array}{c}0.297 \pm 0.23 \\
n=3\end{array}$ & $\begin{aligned} 2.3 & \pm 0.54 \\
n & =3\end{aligned}$ & $\begin{array}{c}47.7 \pm 6.7 \\
n=3\end{array}$ & $\begin{array}{c}1620 \pm 360 \\
n=3\end{array}$ & $\begin{array}{c}3.8 \pm 0.6 \\
n=4\end{array}$ \\
\hline $3 b$ & $\begin{array}{l}\text { Hyperthyroid } \\
\left(\mathrm{T}_{4} 25-29 \text { days }\right)\end{array}$ & $\begin{array}{c}94.8 \pm 3.3 \\
n=3\end{array}$ & $\begin{array}{c}0.500 \pm 0.38^{2} \\
n=4\end{array}$ & $\begin{aligned} 1.63 & \pm 0.37 \\
n & =4\end{aligned}$ & $\begin{array}{c}60.5 \pm 7.5^{2} \\
n=4\end{array}$ & $\begin{array}{c}3350 \pm 400^{2} \\
n=4\end{array}$ & \\
\hline
\end{tabular}

${ }^{1} \mathrm{~b}>\mathrm{a}, P<0.05$

${ }^{2} \mathrm{~b}>\mathrm{a}, P<0.01$

${ }^{1}$ These sets of experiments were performed to assess the role of changes in thyroid status on myocardial weight and $\beta$-adrenergic receptors. Groups $1 \mathrm{a}, \mathrm{lb}$ were sacrificed at 15 days of age: euthyroid $v$ s hyperthyroid (treated on day $7-14$ with thyroxine). Groups $2 \mathrm{a}, 2 \mathrm{~b}$ were maintained with the dam on PTU; $2 \mathrm{a}$ received $0.1 \mathrm{cc} 0.9 \%$ saline each day, $2 \mathrm{~b}$ received $3 \mathrm{mg} / \mathrm{kg}$ T4 each day on days $25-28$ and sacrificed on day 29 . Values represent the mean \pm S.D., $n=$ the number of individual determinations when different from the number of pups. Groups $3 \mathrm{a}$ and $3 \mathrm{~b}$ were normal control rat pups, $3 \mathrm{a}$ received $0.9 \%$ saline and $3 \mathrm{~b}$ received $3 \mathrm{mg} / \mathrm{kg} \mathrm{T}_{4}$ each day on days $25-29$, both groups were sacrificed on day 29 . Significant decreases were assessed by Student $t$ test between $(a)$ and $(b)$ of each group.

Table 4. Effects of thyroid status on adenylate cyclase activity ${ }^{1}$

\begin{tabular}{|c|c|c|c|c|}
\hline \multirow[b]{2}{*}{ Group } & \multicolumn{4}{|c|}{ Adenylate cyclase activity $\left(\right.$ pmoles $\cdot \mathrm{mg}^{-1} \cdot \mathrm{min}^{-1}$ ) } \\
\hline & Basal & $\begin{array}{c}\mathrm{GTP} \\
5 \cdot 10^{-5} \mathrm{M} \\
\end{array}$ & $\begin{array}{c}\text { GTP }\left(5 \cdot 10^{-5} \mathrm{M}\right) \\
\text { Epinephrine }\left(5 \cdot 10^{-5} \mathrm{M}\right)\end{array}$ & $\mathrm{NaF}(10 \mathrm{mM})$ \\
\hline $\begin{array}{l}\text { I day } 28 \text { hypothyroid } \\
\text { (PTU) }\end{array}$ & $\begin{aligned} 8.95 & \pm 2.25 \\
n & =5\end{aligned}$ & $\begin{array}{l}21.2 \pm 6.0 \\
n=5\end{array}$ & $\begin{aligned} 28.9 & \pm 7.8^{1} \\
n & =5\end{aligned}$ & $\begin{aligned} 70.2 & \pm 19.8 \\
n & =5\end{aligned}$ \\
\hline $\begin{array}{l}\text { II } 28 \text { day Euthyroid } \\
\left(\mathrm{PTU}+\mathrm{T}_{4}\right)\end{array}$ & $\begin{aligned} 10.5 & \pm 2.4 \\
n & =3\end{aligned}$ & $\begin{array}{c}22.9 \pm 0.8 \\
n=4\end{array}$ & $\begin{array}{c}46.2 \pm 2.9 \\
n=4\end{array}$ & $\begin{aligned} 64.7 & \pm 6.6 \\
n & =3\end{aligned}$ \\
\hline III 29 day Control & $\begin{array}{c}11.1 \pm 1.4 \\
n=7\end{array}$ & $\begin{array}{c}23.9 \pm 3.6 \\
n=7\end{array}$ & $\begin{array}{c}44.0 \pm 3.5 \\
n=7\end{array}$ & $\begin{array}{c}61.8 \pm 5.9 \\
n=7\end{array}$ \\
\hline $\begin{array}{l}\text { IV } 29 \text { day Hyperthyroid } \\
\left(\mathrm{T}_{4}\right)\end{array}$ & $\begin{aligned} 14.3 & \pm 2.0 \\
n & =4\end{aligned}$ & $\begin{array}{c}24.3 \pm 2.2 \\
n=4\end{array}$ & $\begin{array}{c}45.9 \pm 2.4 \\
n=4\end{array}$ & $\begin{aligned} 58.8 & \pm 4.5 \\
n & =4\end{aligned}$ \\
\hline
\end{tabular}

'Adenylate cyclase activity was determined in washed membrane preparations in the presence or absence of $5 \cdot 10^{-5} \mathrm{M}$ epinephrine, $5 \cdot 10^{-5} \mathrm{M} \mathrm{GTP}$, and $10 \mathrm{mM} \mathrm{NaF}$ at $30^{\circ} \mathrm{C}$. There was no significant difference between Group II and III controls or Group IV (hyperthyroid) on day 28 . Group IV animals were euthyroid animals treated with $3 \mathrm{mg} / \mathrm{kg} \mathrm{T}_{4}$ on days $25-28$, see $3 \mathrm{~b}$, Table 3.

${ }^{2}$ Significant Difference: $P<0.01$, Group I $<$ Groups II, III, IV.

NaF-, GTP- and Gpp(NH)p-(latter not shown) dependent activities were not altered by thyroid status, suggesting that reduction in activity was specific for the $\beta$-adrenergic receptor system. Short term hyperthyroidism in the weanling rat resulted in marked myocardial hypertrophy, a small but significant increase in $\beta$ adrenergic receptor specific activity, no significant change in catecholamine dependent adenylate cyclase activation and more than doubling of the total $\beta$-receptor number (per heart). The significance and mechanism of the lack of an effect of hyperthyroidism on catecholamine-sensitive adenylate cyclase is unclear at present; however, the present finding is in general agreement with that reported in myocardium from adult hyperthyroid rats (17).

The relationships among growth, $\beta$-adrenergic receptors and thyroid status in developing rat myocardium differed from those previously demonstrated by this laboratory in developing rat lung (20). Pulmonary $\beta$-adrenergic receptors increased nearly independently of thyroid status up to day 15 in hypothyroid rat pups. Further increases in lung $\beta$-adrenergic receptors to adult levels at 28 days of age were entirely thyroid hormone dependent. Rats made hypothyroid after reaching maturity did not have fewer pulmonary $\beta$-adrenergic receptors. Thus in the lung there does not appear to be a direct relationship between thyroid status and $\beta$-adrenergic receptor number. The thyroid-hormone-dependent regulation of lung $\beta$-adrenergic receptors is clearly related to the age of the rat pup (postnatal ages 15-28 days). In contrast, at all ages presently studied, thyroid status was more closely associated with the number of $\beta$-adrenergic receptors present in the rat ventricle.

In conclusion, we have demonstrated a relationship between thyroid status and both myocardial hypertrophy and the $\beta$-adrenergic receptors in the developing rat ventricle. Thyroid hormones or thyroid-hormone-dependent factors are required for normal hypertrophic growth of the ventricle in the suckling and weanling rat. Congenital and postnatal hypothyroidism is associated with decrease ventricular $\beta$-adrenergic receptors in the developing rat heart at all ages studied.

\section{REFERENCES AND NOTES}

1. Adolph, E. F.: Ontogeny of heart-rate controls in hamster, rat and guinea pig. Amer. J. Physiol., 220: 1896 (1971).

2. Baker, S. P. and Potter, L. T.: Cardiac $\beta$-adrenoreceptors during normal growth of male and female rats. Br. J. Pharmac., 68: 65 (1980).

3. Banerjee, S. P. and Kung, L. S.: $\beta$-Adrenergic Receptors in Rat Heart: Effects of Thyroidectomy. Europ. J. Pharm., 43: 207 (1977).

4. Brasel. J. A. and Winick, M.: Differential cellular growth in the organs of hypothyroid rats. Growth, 34: 197 (1970).

5. Burton, K.: A study of the conditions and mechanisms of the diphenylamine 
reaction for the colorimetric estimation of deoxyribonucleic acid. Biochem. $J$., 62: 315 (1956).

6. Ciaraldi, T. and Marinetti, G. U.: Thyroxine and propylthiouracil effects in vivo on alpha and beta adrenergic receptors in rat heart. Biochem. Biophys. Res. Comm., 74: 984 (1977).

7. Clark, J. B., Vinicor, F., Carr, L., and Clark, C. M.: Adenylate cyclase responsiveness to guanyl nucleotides in the developing rat heart. Pediatr. Res., 14: 291 (1980).

8. Dussault, J. H. and Labrie, F.: Development of the hypothalmic pituitary-thyroid axis in the neonatal rat. Endocrinology, 97: 1321 (1975).

9. Greenberg, A. H., Najjar, S. and Blizzard, R. M.: Effects of thyroid hormone on growth, differentiation and development. In: Handbook of Physiology and Endocrinology, Thyroid. Vol. III American Physiologic Society, pp. 377-389, (Williams and Wilkins Co., Baltimore, 1977).

10. Hamburgh, M., Lynn, E., and Weiss, E. P.: Analysis of the influence of thyroid hormone on prenatal and postnatal maturation of the rat. Anat. Rec., 150: 147 (1964).

11. Korecky, B. and Rakusan, K.: Normal and hypertrophic growth of the rat heart: changes in cell dimensions and number. Am. J. Physiology, 234: H123 (1978)

12. Lowry, O. H., Rosebrough, N. J., Farr, A. L., and Randall, R. J.: Protein measurement with the folin phenol reagent. J. Biol. Chem., 193: 265 (1951).

13. Page, E. and McCallister, L. P.: Quantitative electron microscopic description of heart muscle cells: Application to normal, hypertrophic and thyroxine-stimulated hearts. Am. J. Cardiol., 31: 172 (1973).

14. Salomon, Y., Londos, C. and Rodbell, M.: A highly sensitive adenylate cyclase assay. Anal. Biochem., 58: 541 (1974).

15. Schefler, W. C.: Statistics for the Biological Sciences, 2nd Edition. (AdditonWesley Publishing Co., Reading, MA, 1979).

16. Tsai, J. S. and Chen, A.: Effect of L-triiodothyronine on $(-)^{3} \mathrm{H}$-dihydroalprenclol binding and cyclic AMP response to $(-)$ adrenaline in cultured heart cells
Nature, 275: 138 (1978).

17. Tse, J., Wrenn, R. W. and Kuo, J. F.: Thyroid-induced changes in characteristics and activities of $\beta$-adrenergic receptors and adenosine $3^{\prime}, 5^{\prime}$ nyphen-monophosphate and guanosine $3^{\prime}, 5^{\prime}$-monophosphate systems in the heart may be related to reputed catecholamine supersensitivity. Endocrinology, 107:6 (1980).

18. Werner, S. C., Hyperthyroidism in The Thyroid. S. C. Werner and S. H. Ingbar, Editors. 4th edition. pp. 591-603. (Harper and Row publishers, New York, 1978).

19. Whitsett, J. A. and Darovec-Beckerman, C.: Developmental aspects of $\beta$-adrenergic receptors and catecholamine sensitive adenylate cyclase in the rat myocardium. Pediatr. Res., 15: 1363 (1981).

20. Whitsett, J. A., Darovec-Beckerman, C., Adams, K. Pollinger, J., and Needelman, $H .:$ Thyroid dependent maturation of $\beta$-adrenergic receptors in the rat lung. Biochem. and Biophysical Research Communications, 97: 913 (1980).

21. Williams, L. T., Lefkowitz, R. J., Watanabe, A. M., Hathaway, D. R. and Besch, H. R.: Thyroid hormone regulation of $\beta$-adrenergic receptor number. J. Biol. Chem., 252: 2787 (1977).

22. Winick, M. and Noble, A.: Quantitative changes in DNA, RNA and protein during neonatal and postnatal growth in the rat. Developmental Biology, I2: 451 (1965).

23. Zak, R.: Cell proliferation during cardiac growth. Amer. J. Cardiology, 31: 211 (1973).

24. Requests for reprints should be addressed to: Dr. Jeffrey A. Whitsett, Children's Hospital, Newborn Division of Pediatrics, University of Cincinnati College of Medicine, 23I Bethesda Avenue, Cincinnati, OH 45267.

25. This research was supported by Children's Hospital Research Foundation, Cincinnati $\mathrm{OH}$ and NICHD Grant No. 11725

26. Received for publication June 3, 1981.

27. Accepted for publication October 22, 1981. 